\title{
Classifying economics for the common good: \\ Connecting sustainable development goals to JEL codes
}

\author{
Jussi Heikkilä ${ }^{1}$
}

April 2020 version

\begin{abstract}
How does economics research help in solving societal challenges? This brief note sheds additional light on this question by providing ways to connect Journal of Economic Literature (JEL) codes and Sustainable Development Goals (SDGs) of the United Nations. These simple linkages illustrate that the themes of SDGs have corresponding JEL classification codes. As the mappings presented here are necessarily imperfect and incomplete, there is plenty of room for improvements. In an ideal world, there would be a JEL classification system for SDGs, a separate JEL code for each of the 17 SDGs.
\end{abstract}

Keywords: JEL codes, social development goals, Agenda 2030, keyword search

JEL codes: A11, O20, Q01

${ }^{1}$ email: jussi.heikkila@jyu.fi I thank Salla Laukkanen for excellent research assistance. 


\section{Introduction}

Economists play an increasingly important role in helping governments design new policies and regulations (Duflo 2017) but how does academic economics research help in solving global challenges? One way to analyse this is to explore the link between economic research and the Sustainable Development Goals (SDGs, LaFleur 2019). In 2015, the member states of the United Nations adopted 17 sustainable development goals, as part of the 2030 Agenda for Sustainable Development (United Nations 2015a). Great progress has been made but there is still a lot of work to do before achieving these goals (United Nations 2019). ${ }^{2}$ Indexing and classification of documents are important since they decreases search costs and therefore promote efficient allocation of attention. In the context of economics research, Journal of Economic Literature (JEL) codes have been used to classify economic research since the early $20^{\text {th }}$ century (Cherrier, 2019). However, there does not yet exist an explicit JEL coding for sustainable development goals.

This brief note suggests that the existing classification systems of economic literature could be utilized to track how much attention is allocated within economics research to topics that are related to global challenges. The contribution of this brief note to existing literature is to connect SDGs to JEL codes. The remainder of the paper is organized as follows. Section 2 presents SDGs and JEL classification system. Section 3 links JEL codes and SDGs goal by goal and discusses the limitations. Section 4 concludes.

\section{SDGs and JEL codes}

\subsection{SDGs}

According to the United Nations, sustainable development is defined as "development that meets the needs of the present without compromising the ability of future generations to meet their own needs". ${ }^{3}$ The 17 sustainable development goals succeeded the United Nations' eight Millennium development goals (MDGs) in 2015 (United Nations 2015a, 2015b). ${ }^{4}$ The eight MDGs were international development goals for the year 2015 established following the Millennium Summit of the United Nations and adoption of the United Nations Millennium Declaration in September $2000 .^{5}$ In September 2015, 193 countries of the UN General Assembly adopted the 2030 Development Agenda ("Agenda 2030") which paragraph 59 outlines the 17 Sustainable Development Goals and the associated 169 targets and 232 indicators (United Nations 2015a). Currently, the aim is to achieve all SDGs by 2030 and the progress is monitored continuously (United Nations 2015, 2019; Sachs 2019). The 17 SDGs are:

\footnotetext{
${ }^{2}$ See e.g. SDG Tracker of Our World In data: https://sdg-tracker.org/ (Accessed on 21 March 2020), Sustainable Development Report: https://www.sdgindex.org/ (Accessed on 21 March 2020) and Sachs et al. (2019).

${ }^{3}$ See https://www.un.org/sustainabledevelopment/development-agenda/ Accessed on 21 Mar 2020.

${ }^{4}$ The MDGs were: Goal 1. Eradicate extreme poverty and hunger; Goal 2. Achieve universal primary education; Goal 3. Promote gender equality and empower women; Goal 4. Reduce child mortality; Goal 5. Improve maternal health; Goal 6. Combating HIV/AIDS, malaria, and other diseases; Goal 7. Ensure environmental sustainability; Goal 8. Develop a global partnership for development. See Millennium development goals: https://www.un.org/millenniumgoals/ SDGs: https://www.un.org/sustainabledevelopment/sustainable-developmentgoals/ Accessed on 21 March 2020.

${ }^{5}$ See https://www.un.org/millenniumgoals/bkgd.shtml Accessed on 4 April 2020
} 
Goal 1. End poverty in all its forms everywhere

Goal 2. End hunger, achieve food security and improved nutrition and promote sustainable agriculture

Goal 3. Ensure healthy lives and promote well-being for all at all ages

Goal 4. Ensure inclusive and equitable quality education and promote lifelong learning opportunities for all

Goal 5. Achieve gender equality and empower all women and girls

Goal 6. Ensure availability and sustainable management of water and sanitation for all

Goal 7. Ensure access to affordable, reliable, sustainable and modern energy for all

Goal 8. Promote sustained, inclusive and sustainable economic growth, full and productive employment and decent work for all

Goal 9. Build resilient infrastructure, promote inclusive and sustainable industrialization and foster innovation

Goal 10. Reduce inequality within and among countries

Goal 11. Make cities and human settlements inclusive, safe, resilient and sustainable

Goal 12. Ensure sustainable consumption and production patterns

Goal 13. Take urgent action to combat climate change and its impacts

Goal 14. Conserve and sustainably use the oceans, seas and marine resources for sustainable development

Goal 15. Protect, restore and promote sustainable use of terrestrial ecosystems, sustainably manage forests, combat desertification, and halt and reverse land degradation and halt biodiversity loss

Goal 16. Promote peaceful and inclusive societies for sustainable development, provide access to justice for all and build effective, accountable and inclusive institutions at all levels

Goal 17. Strengthen the means of implementation and revitalize the global partnership for sustainable development

In order to get a rough overview of the occurrence of MDGs and SDGs in economics research during the past two decades, we conduct some very general keyword searches. Figure 2 shows the trends of simple keyword searches in IDEAS/RePEc bibliographic database ${ }^{6}$ for both search queries "sustainable development goal" and "millennium development goal". As expected, the trends in the number of publications clearly show that SDGs have replaced MDGs after Agenda 2030 was introduced in 2015. It is also noteworthy that the increase in the number of research papers mentioning SDGs is growing very steeply.

\footnotetext{
${ }^{6}$ IDEAS is an economics-focused bibliographic database with over 3,100,000 indexed items of research, see https://ideas.repec.org/. It is based on RePEc database, see http://repec.org/. Accessed on 4 April 2020.
} 
Figure 1. Publications mentioning MDGs or SDGs

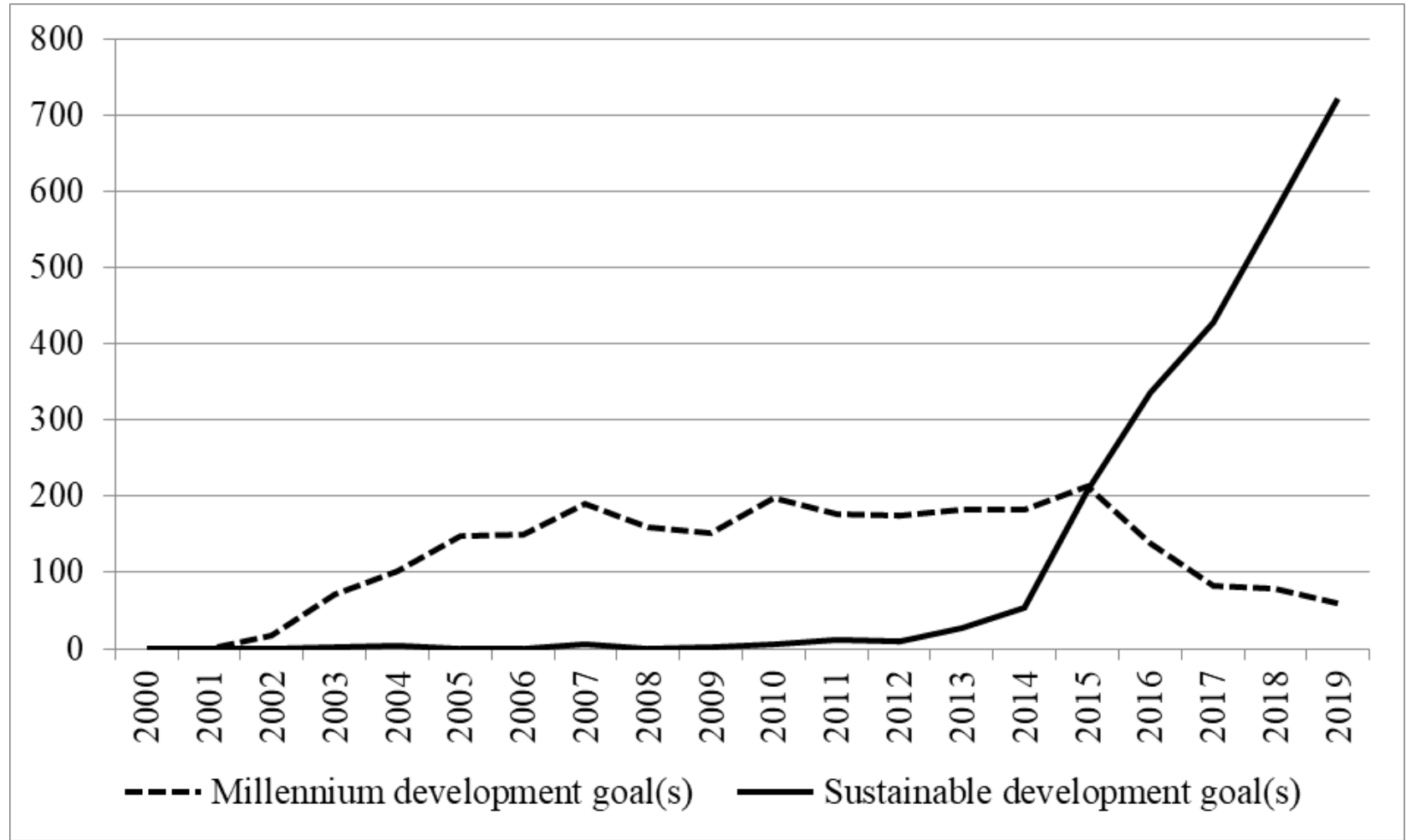

Notes: Source is IDEAS/RePEc search, available at https://ideas.repec.org/search.html. Search queries: SDGs "sustainable development goal" OR "sustainable development goals" and MDGs "millennium development goal" OR "millennium development goals". No filters applied, i.e., search "All” (incl. Articles, Papers, Chapters, Books, Software) in "Whole record". Retrieved on 4 April 2020.

\subsection{JEL codes}

In the field of economics, Journal of Economic Literature classification is the de facto standard in classifying articles (Cherrier 2017; Kosnik 2018). Majority of economics journals require authors to choose JEL codes which best describe their manuscripts when submitting (Kosnik 2018) and bibliographic databases such as IDEAS and SSRN allow users to browse articles by JEL codes. The first version of the JEL codes (or EconLit subject descriptors) by the American Economic Association (AEA) was published in 1911 and it has since been occasionally updated and extended (Cherrier 2017). According to the webpage of the AEA:

"The JEL classification system was developed for use in the Journal of Economic Literature (JEL), and is a standard method of classifying scholarly literature in the field of economics. The system is used to classify articles, dissertations, books, book reviews, and working papers in EconLit, and in many other applications. "7

As of the beginning of 2020, there are 20 JEL categories, which have 122 second level subcategories that have altogether 856 third level sub-categories. Table 1 shows that the number of subcategories varies across main JEL classes. Interestingly, despite the important role of JEL codes, they have received only limited attention in research until recently (Cherrier 2017; Kosnik 2018).

\footnotetext{
${ }^{7}$ https://www.aeaweb.org/econlit/jelCodes.php?view=jel Accessed on 21 March 2020.
} 
Table 1. JEL codes

\begin{tabular}{|c|c|c|c|}
\hline & 1st level JEL codes & $\begin{array}{c}\text { Number of } 2 \text { nd } \\
\text { level codes }\end{array}$ & $\begin{array}{c}\text { Number of } 3 \text { rd } \\
\text { level codes }\end{array}$ \\
\hline 1 & A General Economics and Teaching & 3 & 16 \\
\hline 2 & $\begin{array}{l}\text { B History of Economic Thought, Methodology, and Heterodox } \\
\text { Approaches }\end{array}$ & 5 & 32 \\
\hline 3 & C Mathematical and Quantitative Methods & 9 & 70 \\
\hline 4 & D Microeconomics & 9 & 65 \\
\hline 5 & E Macroeconomics and Monetary Economics & 7 & 47 \\
\hline 6 & F International Economics & 6 & 53 \\
\hline 7 & G Financial Economics & 5 & 33 \\
\hline 8 & H Public Economics & 8 & 56 \\
\hline 9 & I Health, Education, and Welfare & 3 & 23 \\
\hline 10 & J Labor and Demographic Economics & 8 & 62 \\
\hline 11 & K Law and Economics & 4 & 30 \\
\hline 12 & L Industrial Organization & 9 & 72 \\
\hline 13 & $\begin{array}{l}\text { M Business Administration and Business Economics, Marketing, } \\
\text { Accounting, Personnel Economics }\end{array}$ & 5 & 29 \\
\hline 14 & N Economic History & 9 & 74 \\
\hline 15 & O Economic Development, Innovation, Technological Change, and Growth & 5 & 41 \\
\hline 16 & P Economic Systems & 5 & 43 \\
\hline 17 & $\begin{array}{l}\text { Q Agricultural and Natural Resource Economics, Environmental and } \\
\text { Ecological Economics }\end{array}$ & 5 & 49 \\
\hline 18 & R Urban, Rural, Regional, Real Estate, and Transportation Economics & 5 & 31 \\
\hline 19 & Y Miscellaneous Categories & 9 & 11 \\
\hline 20 & Z Other Special Topic & 3 & 19 \\
\hline & Min & 3 & 11 \\
\hline & Max & 9 & 74 \\
\hline & Average & 6.10 & 42.80 \\
\hline & Median & 5 & 42 \\
\hline & Total sum & 122 & 856 \\
\hline
\end{tabular}

Notes: "General" JEL classes under 1st level codes with no 2nd level codes (e.g., B00 and C00) have been counted as 3rd level codes.

\section{Connecting SDGs and JEL codes}

\subsection{Methods and data}

In an ideal or the first best world, there would be own JEL classification for SDGs - that is, a separate JEL code for each of the 17 SDGs. However, currently we live in a second best world without this type of classification. ${ }^{8}$ In order to fill in this gap, we provide three simple ways to link

\footnotetext{
${ }^{8}$ Note that JEL code "Q01 Sustainable Development" "covers studies about issues related to sustainable development in the broadest context. That is, studies should include agriculture, natural resources, energy sources, and the environment."
} 
JEL codes and SDGs. In principle, we could either link "each JEL code to the closest SDGs" or "each SDG to the closest JEL codes". We chose the latter option that is much simpler and link 17 SDGs to the most similar $3^{\text {rd }}$ level JEL codes. JEL code data was collected from the AEA's webpage and SDGs were collected from United Nations' webpage (see Section 2). Three alternative methods to establish links between SDGs and JEL codes are described next.

First, we extract keywords directly from the 17 SDGs (Section 2.1) and search over the keywords of $8563^{\text {rd }}$ level JEL codes (Table 1) to document the number of potentially related JEL codes. For instance, the keyword for Goal 1 "End poverty in all its forms everywhere" is "poverty". Some SDGs are more broadly defined and are assigned more keywords correspondingly: For instance, the keywords for Goal 9 "Build resilient infrastructure, promote inclusive and sustainable industrialization and foster innovation" are "infrastructure", "industrialization" and "innovation". We provide examples of JEL codes that most closely relate to the selected keywords.

Second, we build on LaFleur (2019) who created an SDG classification system for DESA publications. LaFleur (2019) was among the first to analyze United Nations publications using machine-learning approach to compute how much each SDG is represented in individual publications. ${ }^{9}$ As part of his analysis, LaFleur (2019) used machine learning methods to identify keywords related to each SDG and we use a slightly modified version of his keyword list as a basis to match SDGs to JELs. For each SDG, we rank JEL codes according to the number of overlapping keywords. These keywords are presented in Table 2. We explore three different weightings for the keywords: 1) no weighting, 2) weight $1 / 1$ for the $1^{\text {st }}$ keyword, $1 / 2$ for the $2^{\text {nd }}, 1 / 3$ for the $3^{\text {rd }}$ and so forth, and 3) weight 1 for the first five keywords and $1 /[$ number of order] for the rest.

Third, we select three most relevant keywords for each SDG from the LaFleur's (2019) list based on elimination and discretion. First, we delete "general words" that clearly are not related solely to a specific SDG such as "change", "impacts", "patterns", "rapid", "added", "policies", "capita" and "nations". Second, we eliminate pairs of words when the same word-pair occurs also separately in the list. Third, in most cases we delete plural forms if the same word is on the list also as singular. Finally, from the remaining set of words, we select three words that most closely relate to corresponding SDG based on discretion. For most SDGs, we are left with three singular nouns as shown in Table 2.

\footnotetext{
${ }^{9}$ See also Körfgen et al. (2018).
} 


\section{Table 2. Keywords for SDGs}

\begin{tabular}{|c|c|c|}
\hline SDG & LaFleur (2019) keywords & Selected three \\
\hline 1 & $\begin{array}{l}\text { poverty social protection poor social_protection extreme disasters extreme_poverty poverty_line } \\
\text { day end_pov-erty line losses living disaster cash protection_systems person poor_vulnerable } \\
\text { disaster_risk }\end{array}$ & poverty poor social_protection \\
\hline 2 & $\begin{array}{l}\text { food hunger agricultural agriculture children malnutrition production genetic prices export markets } \\
\text { hungry food_production subsidies food_security nutrition undernourished breeds aid insecurity }\end{array}$ & food agriculture nutrition \\
\hline 3 & $\begin{array}{l}\text { health deaths diseases people mortality births live_births maternal children hiv age live care rate } \\
\text { years_age reproductive deaths_live worldwide risk women }\end{array}$ & health disease mortality \\
\hline 4 & $\begin{array}{l}\text { education primary children school primary_education quality secondary schools learning } \\
\text { quality_education skills secondary_education reading primary_school proficiency mathematics } \\
\text { teachers minimum saharan basic }\end{array}$ & education school learning \\
\hline 5 & $\begin{array}{l}\text { women girls gender women_girls equality gender_equality violence sexual age marriage female } \\
\text { married work rights genital_mutilation mutilation female_genital genital partner globally }\end{array}$ & women gender equality \\
\hline 6 & $\begin{array}{l}\text { water sanitation management water_sanitation people drinking_water drinking population } \\
\text { improved hygiene facilities safely water_resources global_population wastewater freshwater } \\
\text { water_scarcity scarcity resources water_stress }\end{array}$ & water sanitation hygiene \\
\hline 7 & $\begin{array}{l}\text { energy electricity renewable renewable_energy clean affordable modern cooking fuels access } \\
\text { energy_efficiency energy_consumption energy_intensity intensity consumption } \\
\text { access_electricity reliable efficiency technologies affordable_reliable }\end{array}$ & energy electricity renewable \\
\hline 8 & $\begin{array}{l}\text { growth labour employment unemployment work decent financial productivity decent_work } \\
\text { financial_services productive men adults working youth economic_growth child } \\
\text { labour_productivity jobs developed }\end{array}$ & labor employment productivity \\
\hline 9 & $\begin{array}{l}\text { manufacturing infrastructure developing added manufacturing_added industrialization innovation } \\
\text { gdp devel-oped employment industries industrial mobile research job research_development } \\
\text { intensity resilient_infrastruc-ture resilient emissions }\end{array}$ & infrastructure industrialization innovation \\
\hline 10 & $\begin{array}{l}\text { inequality developed income developing duty exports oda money duty_free developing_states } \\
\text { tariff remit-tances migration treatment reducing inequalities products migrant policies island }\end{array}$ & inequality income migration \\
\hline 11 & $\begin{array}{l}\text { cities urban waste air pollution slums urban_population solid_waste solid land urbanization } \\
\text { management disas-ters air_pollution rapid safe resilient housing inclusive risk }\end{array}$ & cities urban housing \\
\hline 12 & $\begin{array}{l}\text { consumption production material consumption_production sustainable sustainable_consumption } \\
\text { water conven-tion material_consumption food domestic_material domestic impacts patterns natural } \\
\text { capita production_pat-terns environmental pollutants wastes }\end{array}$ & consumption production sustainable \\
\hline 13 & $\begin{array}{l}\text { climate change climate_change agreement paris paris_agreement action global parties emissions } \\
\text { adaptation convention temperature framework nations framework_convention united_nations } \\
\text { determined climate_action degrees }\end{array}$ & climate climate_change emission \\
\hline 14 & $\begin{array}{l}\text { marine oceans ocean coastal resources areas fisheries ecosystems pollution protected_areas } \\
\text { marine_resources fish overfishing biodiversity protected management stocks eutrophication } \\
\text { ocean_acidification acidification }\end{array}$ & marine ocean fish \\
\hline 15 & $\begin{array}{l}\text { biodiversity land species forests areas loss forest degradation wildlife desertification protected } \\
\text { ecosystems ter-restrial conservation resources halt land_degradation management covered } \\
\text { biodiversity_loss }\end{array}$ & biodiversity land forest \\
\hline 16 & $\begin{array}{l}\text { institutions rights justice violence inclusive victims access_justice children human_rights data } \\
\text { human societies trafficking effective peaceful levels sexual forms birth_registration registration }\end{array}$ & institutions rights justice \\
\hline 17 & $\begin{array}{l}\text { developed development data oda developing capacity registration partnerships capacity_building } \\
\text { building regions trade received agenda statistical enhance debt areas complete death_registration }\end{array}$ & development official_development_assistance trade \\
\hline
\end{tabular}

\subsection{Results}

Table 3 reports the results of the simple keyword search approach. We also provide an example of a relevant JEL code for each keyword if there is one. This very simple keyword search already indicates that economic research classification can be relatively easily linked to SDGs. Only for some keywords no matching JEL codes are found (e.g., "girl”, "sanitation"). 
Table 3. Link between SDGs and JEL codes, simple keyword search

\begin{tabular}{|c|c|c|c|}
\hline Sustainable Development Goal & Keywords & $\begin{array}{l}\text { Number of 3rd } \\
\text { level JEL codes }\end{array}$ & Example \\
\hline Goal 1. End poverty in all its forms everywhere & Poverty & 9 & I32 Measurement and Analysis of Poverty \\
\hline \multirow{4}{*}{$\begin{array}{l}\text { Goal } 2 \text {. End hunger, achieve food security and } \\
\text { improved nutrition and promote sustainable agriculture }\end{array}$} & Hunger & 1 & O15 Human Resources $\bullet$ Human Development $•$ Income Distribution $•$ Migration \\
\hline & Food & 12 & Q18 Agricultural Policy • Food Policy \\
\hline & Nutrition & 4 & I12 Health Behavior \\
\hline & Agricultur & 17 & O13 Agriculture $\bullet$ Natural Resources $\bullet$ Energy $\bullet$ Environment $\bullet$ Other Primary Products \\
\hline \multirow{2}{*}{$\begin{array}{l}\text { Goal } 3 \text {. Ensure healthy lives and promote well-being } \\
\text { for all at all ages }\end{array}$} & Health & 21 & I15 Health and Economic Development \\
\hline & Well-being & 3 & I31 General Welfare, Well-Being \\
\hline \multirow{2}{*}{$\begin{array}{l}\text { Goal } 4 \text {. Ensure inclusive and equitable quality } \\
\text { for all }\end{array}$} & Education & 20 & I25 Education and Economic Development \\
\hline & Learning & 5 & J24 Human Capital $\bullet$ Skills $•$ Occupational Choice $\cdot$ Labor Productivity \\
\hline \multirow{3}{*}{$\begin{array}{l}\text { Goal } 5 \text {. Achieve gender equality and empower all } \\
\text { women and girls }\end{array}$} & Gender & 7 & K38 Human Rights Law $\bullet$ Gender Law \\
\hline & Women & 2 & J16 Economics of Gender $\bullet$ Non-labor Discrimination \\
\hline & Girl & 0 & - \\
\hline \multirow{2}{*}{$\begin{array}{l}\text { Goal 6. Ensure availability and sustainable } \\
\text { management of water and sanitation for all }\end{array}$} & Water & 6 & Q25 Water \\
\hline & Sanitation & 0 & - \\
\hline \multirow{4}{*}{$\begin{array}{l}\text { Goal 7. Ensure access to affordable, reliable, } \\
\text { sustainable and modern energy for all } \\
\text { Goal } 8 \text {. Promote sustained, inclusive and sustainable } \\
\text { economic growth, full and productive employment and } \\
\text { decent work for all }\end{array}$} & Energy & 12 & O13 Agriculture $\bullet$ Natural Resources $\bullet$ Energy $\bullet$ Environment $\bullet$ Other Primary Products \\
\hline & Economic growth & 5 & $\begin{array}{l}\text { O47 Empirical Studies of Economic Growth • Aggregate Productivity } \bullet \text { Cross-Country } \\
\text { Output Convergence }\end{array}$ \\
\hline & Employment & 24 & $\begin{array}{l}\text { E24 Employment } \bullet \text { Unemployment } \bullet \text { Wages } \bullet \text { Intergenerational Income Distribution } \bullet \\
\text { Aggregate Human Capital } \bullet \text { Aggregate Labor Productivity }\end{array}$ \\
\hline & Work & 29 & J81 Working Conditions \\
\hline \multirow{3}{*}{$\begin{array}{l}\text { Goal 9. Build resilient infrastructure, promote inclusive } \\
\text { and sustainable industrialization and foster innovation }\end{array}$} & Infrastructure & 9 & H54 Infrastructures • Other Public Investment and Capital Stock \\
\hline & Industrialization & 3 & L52 Industrial Policy $\cdot$ Sectoral Planning Methods \\
\hline & Innovation & 7 & O32 Management of Technological Innovation and R\&D \\
\hline \multirow{4}{*}{$\begin{array}{l}\text { Goal } 10 \text {. Reduce inequality within and among } \\
\text { countries } \\
\text { Goal } 11 \text {. Make cities and human settlements inclusive, } \\
\text { safe, resilient and sustainable }\end{array}$} & Inequality & 12 & $\begin{array}{l}\text { J15 Economics of Minorities, Races, Indigenous Peoples, and Immigrants } • \text { Non-labor } \\
\text { Discrimination }\end{array}$ \\
\hline & Cities & 6 & $\begin{array}{l}\text { R23 Regional Migration } \bullet \text { Regional Labor Markets } \bullet \text { Population } ・ \text { Neighborhood } \\
\text { Characteristics }\end{array}$ \\
\hline & Housing & 11 & R31 Housing Supply and Markets \\
\hline & Transport & 18 & O18 Urban, Rural, Regional, and Transportation Analysis $\bullet$ Housing $\bullet$ Infrastructure \\
\hline \multirow{4}{*}{$\begin{array}{l}\text { Goal } 12 \text {. Ensure sustainable consumption and } \\
\text { production patterns } \\
\text { Goal } 13 \text {. Take urgent action to combat climate change } \\
\text { and its impacts* }\end{array}$} & Consumption & 11 & E21 Consumption $\cdot$ Saving $\cdot$ Wealth \\
\hline & Production & 28 & D62 Externalities \\
\hline & Climate & 3 & Q58 Government Policy \\
\hline & Climate change & 1 & Q54 Climate $\bullet$ Natural Disasters and Their Management $\bullet$ Global Warming \\
\hline $\begin{array}{l}\text { Goal } 14 \text {. Conserve and sustainably use the oceans, } \\
\text { seas and marine resources for sustainable } \\
\text { development }\end{array}$ & $\begin{array}{l}\text { Ocean } \\
\text { Marine or maritime }\end{array}$ & $\begin{array}{l}2 \\
2\end{array}$ & $\begin{array}{l}\text { Q25 Water } \\
\text { Q22 Fishery • Aquaculture }\end{array}$ \\
\hline \multirow{5}{*}{$\begin{array}{l}\text { Goal } 15 \text {. Protect, restore and promote sustainable use } \\
\text { of terrestrial ecosystems, sustainably manage forests, } \\
\text { combat desertification, and halt and reverse land } \\
\text { degradation and halt biodiversity loss }\end{array}$} & Ecosystem & 2 & $\begin{array}{l}\text { Q57 Ecological Economics: Ecosystem Services • Biodiversity Conservation } • \\
\text { Bioeconomics • Industrial Ecology }\end{array}$ \\
\hline & Forest & 3 & Q23 Forestry \\
\hline & Desertification & 3 & O13 Agriculture $\bullet$ Natural Resources $\bullet$ Energy $\bullet$ Environment $\bullet$ Other Primary Products \\
\hline & Land & 17 & Q24 Land \\
\hline & Biodiversity & 1 & $\begin{array}{l}\text { Q57 Ecological Economics: Ecosystem Services • Biodiversity Conservation • } \\
\text { Bioeconomics • Industrial Ecology }\end{array}$ \\
\hline \multirow{3}{*}{$\begin{array}{l}\text { Goal 16. Promote peaceful and inclusive societies for } \\
\text { sustainable development, provide access to justice for } \\
\text { all and build effective, accountable and inclusive }\end{array}$} & Peace & 2 & D74 Conflict $\cdot$ Conflict Resolution $\cdot$ Alliances $\cdot$ Revolutions \\
\hline & Justice & 3 & D63 Equity, Justice, Inequality, and Other Normative Criteria and Measurement \\
\hline & Institution & 22 & D02 Institutions: Design, Formation, Operations, and Impact \\
\hline \multirow{2}{*}{$\begin{array}{l}\text { Goal 17. Strengthen the means of implementation and } \\
\text { revitalize the global partnership for sustainable } \\
\text { development }\end{array}$} & International & 63 & F02 International Economic Order and Integration \\
\hline & & & \\
\hline
\end{tabular}

Table 4 lists for each SDG three $3^{\text {rd }}$ level JEL codes that have the most overlap with keywords suggested by LaFleur (2019). We explored three different weightings based on the ranking of keywords and they produced relatively similar rankings for JEL codes. Table 4 reports the results for the third weighting option (see Section 3.1). For most SDGs, there are JEL codes that clearly have most keyword overlap with LaFleur's keywords, whereas for some the best matching JEL codes are not so unambiguous. In other words, there are several JEL codes with equal amount of keyword overlap. Most of the identified JEL codes seem to match SDGs quite well. One example of an exception is Goal 13 where JEL code C22 "Time-series models" overlaps in keywords but is not actually related specifically to the substance of Goal 13 . 
Table 5 is otherwise similar to Table 4 except that there the number of keywords for each SDG is limited to three most relevant ones (see Table 2). The resulting JEL codes are in most cases the same as in Table 4 but for some there is less overlap. For instance, for SDG 17 the top three JEL codes are all different in Tables 4 and 5. To summarize, these very simple keyword similarity analyses suggest that it is possible to connect SDGs and JEL codes. Thus, economists may classify their research articles to JEL codes that are closely linked to SDGs. 
Table 4. Link between SDGs and JEL codes, modified keywords of LaFleur (2019)

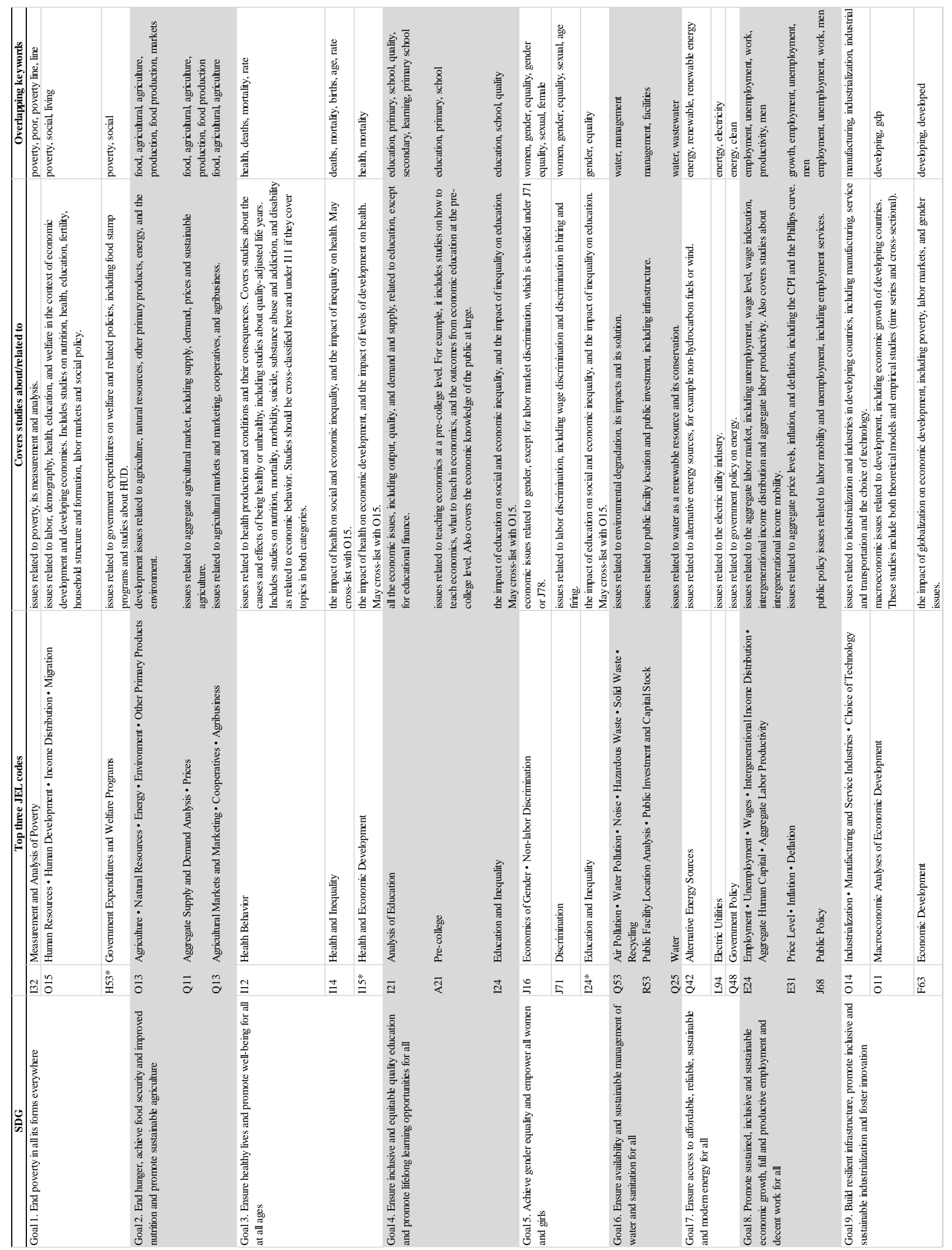


Table 4. Continued

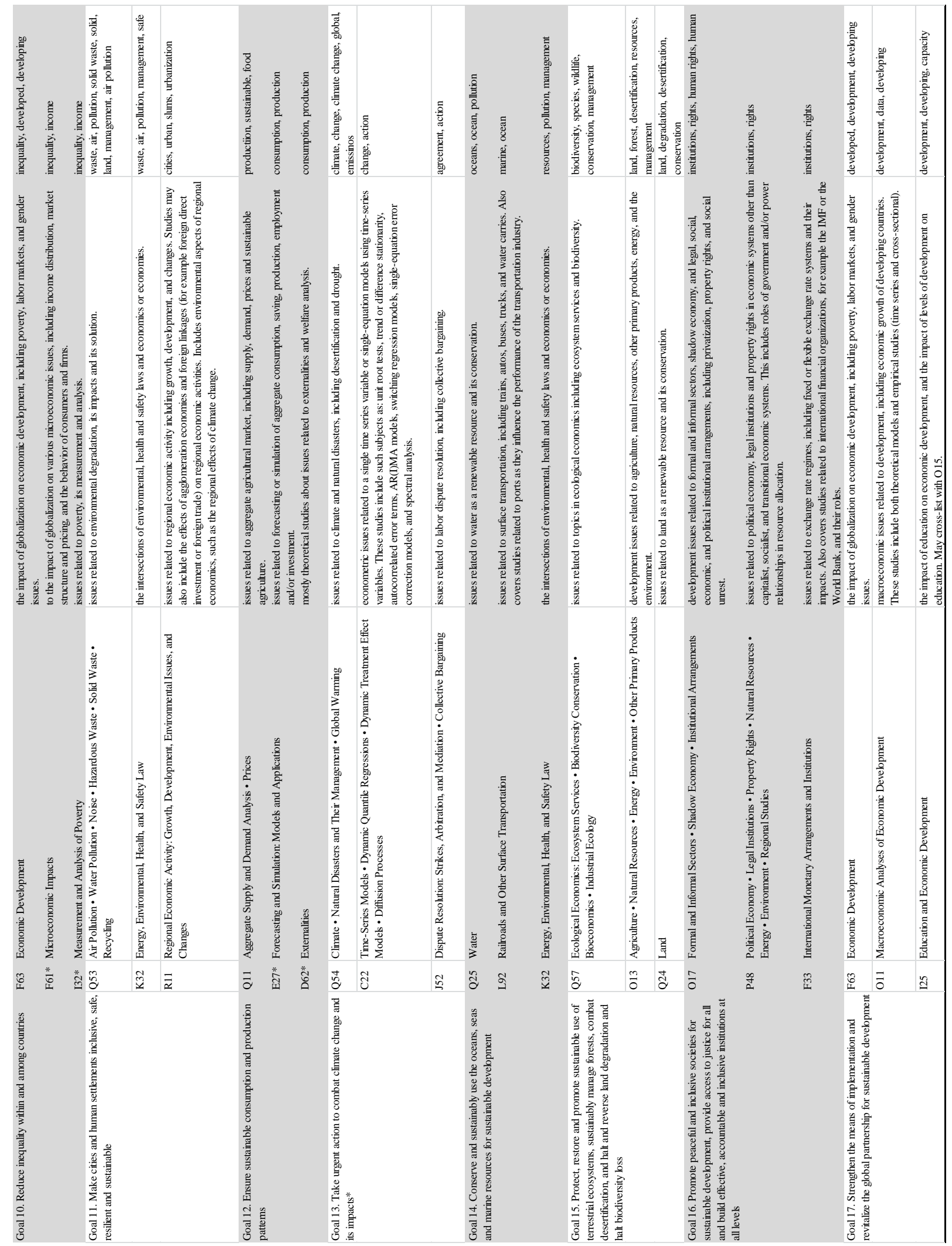

Notes: * refers to cases where there are also other JEL codes with equal keyword overlap and the choice of this specific JEL code among the top three is based on discretion. Ranking of the top3 JEL codes is based on the following weighting: weight 1 for the first five keywords and $1 /[$ number of order] for the rest. Data available from the author upon request. 
Table 5. Link between SDGs and JEL codes, selected three keywords

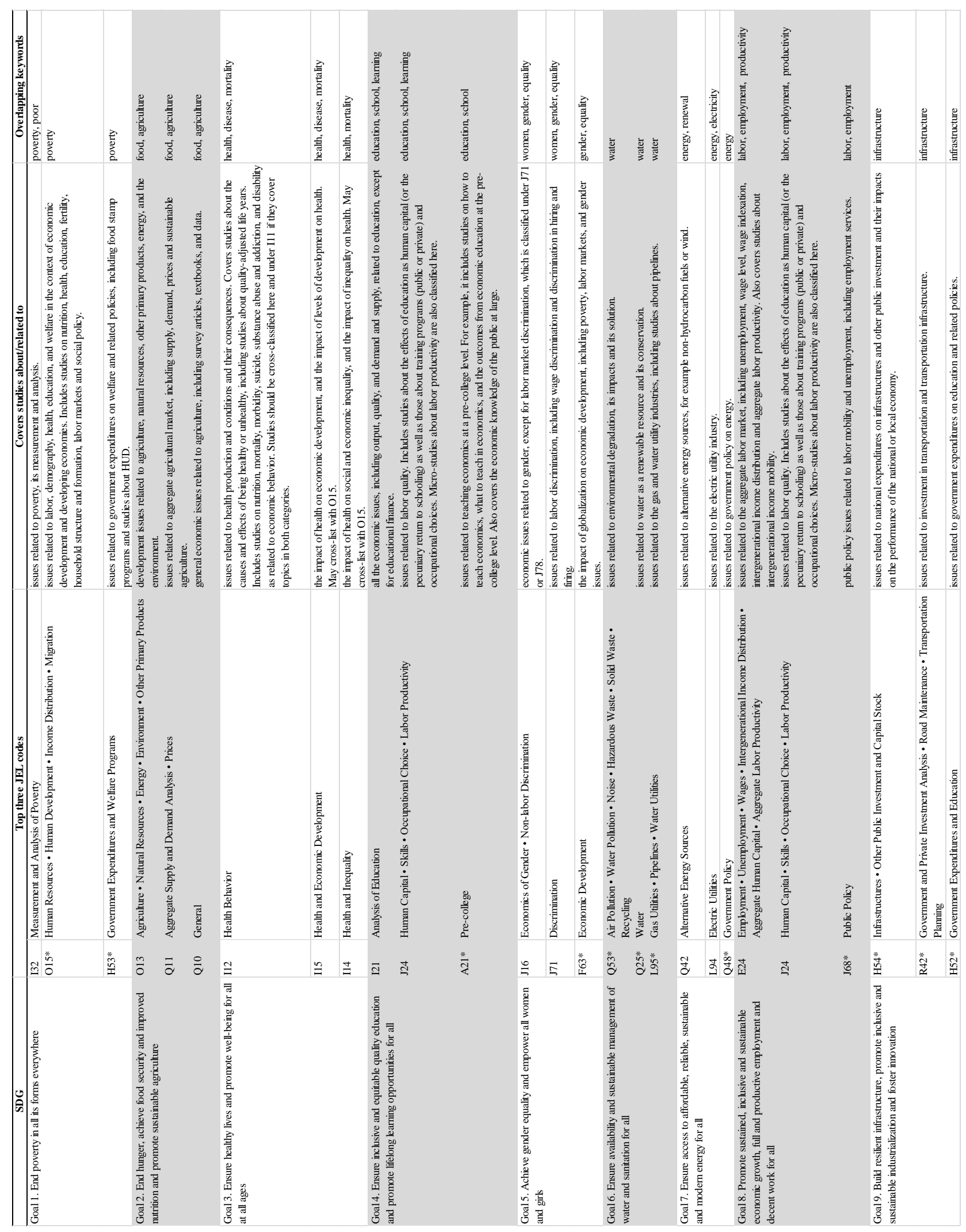




\section{Table 5. Continued}

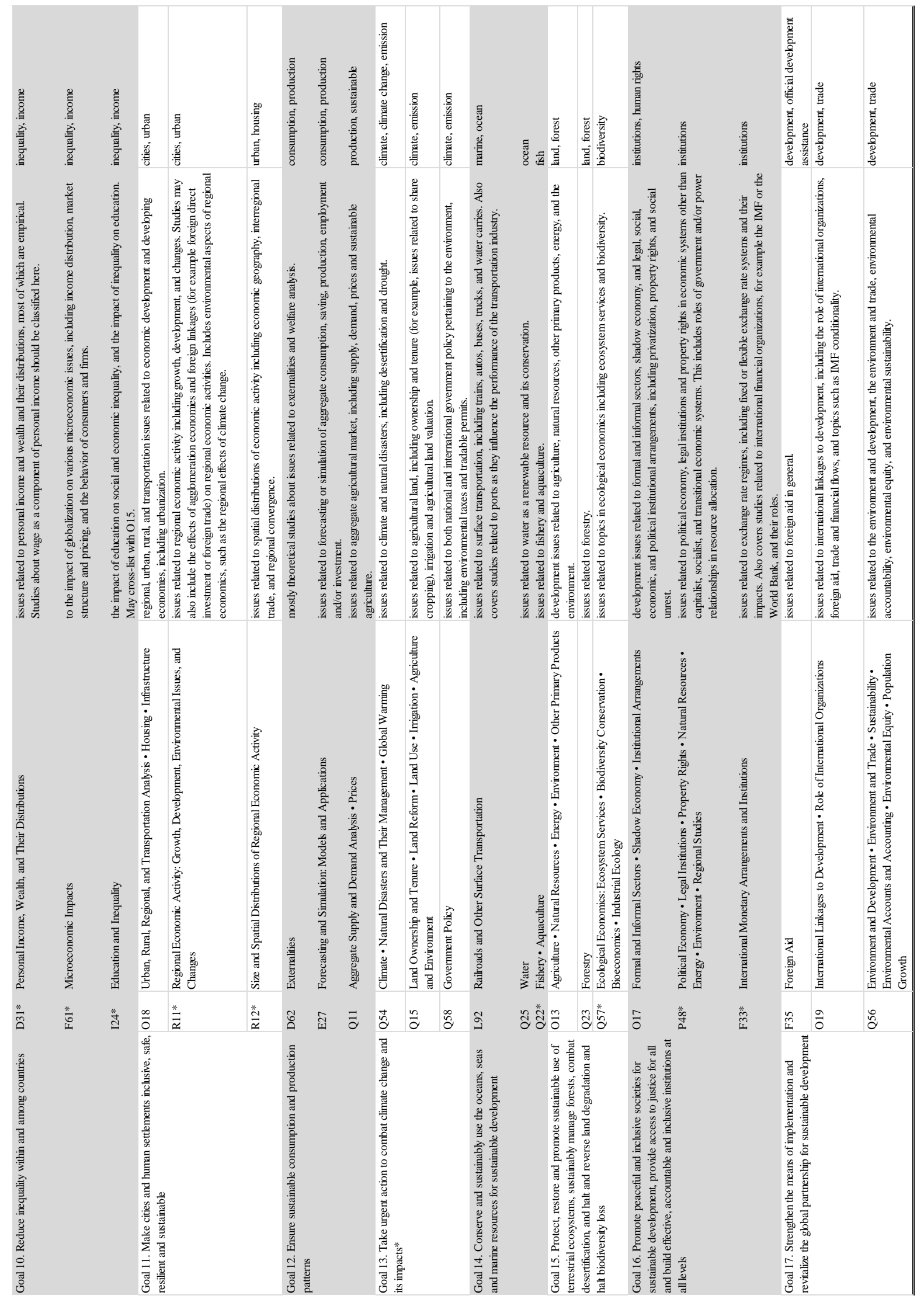

Notes: * refers to cases where there are also other JEL codes with equal keyword overlap and the choice of this specific JEL code among the top three is based on discretion. Data available from the author upon request. 
The mappings presented in Tables 3, 4 and 5 are examples of very simple ways to link JEL codes and SDGs and there are naturally multiple other ways. In other words, they are necessarily imperfect and incomplete and have several limitations. It is worth noting that some JEL codes cannot be directly linked to specific SDGs. For instance, economic methods (e.g., JEL code class C "Mathematical and Quantitative Methods" with its subclasses) are "general purpose technologies" and are not SDG-specific but can be applied to study all of them. It should also be noted that for some JEL codes the guideline mentions that documents classified to that specific JEL code may, or in some cases should, be "cross-listed" or "cross-classified" to other JEL codes. For instance, the guideline for JEL code "I15 Health and Economic Development" notes that it "covers studies about the impact of health on economic development, and the impact of levels of development on health. May cross-list with O15" (see Goal 3 in Table 4). Similarly, the guideline for JEL code "J83 Workers' Rights" notes that it "covers studies about labor standard issues related to workers' rights. Studies should be cross-classified here and under the other appropriate categories in $\mathrm{J}$, if they are relevant." These nuances in JEL- code-specific guidelines were ignored in this article.

\section{Discussion}

As the sustainable development goals lack their corresponding JEL codes, this paper has suggested simple ways to connect SDGs and JEL codes. There are multiple ways to improve these linkages. For instance, one could use the corpus or keywords of economics articles that are tagged with a specific JEL code to establish the link to the closest SDGs. This would require much deeper bibliometric, topic modelling and science mapping analyses (cf. Aria \& Cuccurullo 2017; Körfgen et al. 2018; Ambrosino et al. 2019; LaFleur 2019). These are left for future studies.

The correspondence between economic research topics and SDGs illustrates that economics is not after all so dismal science as some may think. Highlighting the fact that economists study research topics that are closely related to SDGs may encourage other researchers to allocate more attention on analysing how economic research can help in solving societal challenges and reaching all the SDGs by 2030 .

\section{References}

Ambrosino, A., Cedrini, M., Davis, J., Fiori, S., Guerzoni, M. \& Nuccio, M. 2019. What topic modeling could reveal about the evolution of economics. Journal of Economic Methodology 25(4), $329-348$.

Aria, M. \& Cuccurullo, C. 2017. bibliometrix: An R-tool for comprehensive science mapping analysis. bibliometrix: An R-tool for comprehensive science mapping analysis. Journal of Informetrics 11, 959-975.

Cherrier, B. 2017. Classifying Economics: A History of the JEL Codes. Journal of Economic Literature, 55(2): 545-79. 
Duflo, E. 2017. "Richard T. Ely Lecture: The Economist as Plumber." American Economic Review, 107(5): 1-26.

Kosnik, L. 2018 A survey of JEL codes: What do they mean and are they used consistently? Journal of Economic Surveys 32(1), 249-272.

Körfgen, A., Förster, K., Glatz, I., Maier, S., Becsi, B., Meyer, A., Kromp-Kolb, H. \& Stötter, J. 2018. It's a Hit! Mapping Austrian Research Contributions to the Sustainable Development Goals. Sustainability 10(9).

LaFleur, M. 2019, Art is long, life is short: An SDG Classification System for DESA Publications. DESA Working Paper No. 159ST/ESA/2019/DWP/159, May 2019.

Sachs, J., Schmidt-Traub, G., Kroll, C., Lafortune, G., \& Fuller, G. 2019. Sustainable development report 2019. Bertelsmann Stiftung and Sustainable Development Solutions Network (SDSN), New York.

United Nations. 2015a. Transforming Our World: The 2030 Agenda for Sustainable Development. United Nations, New York.

United Nations. 2015b. The Millennium Development Goals Report 2015. United Nations, New York.

United Nations. 2019. The Sustainable Development Goals Report 2019. United Nations, New York. 